\title{
MOLECULAR DETECTION AND GENETIC ANALYSIS OF THEILERIA EQUI DETECTED IN APPARENTLY HEALTHY HORSES IN NIGERIA
}

\author{
Takeet, M. I. ${ }^{1}$, Ademola, I. O. ${ }^{2}$, Adejinmi, J. O. ${ }^{2}$ \\ Mosaku, E. I. ${ }^{1}$, Abakpa, S. A. V. ${ }^{3}$, Peters, S. O. ${ }^{4}$ \\ ${ }^{1}$ Department of Veterinary Parasitology and Entomology, College of Veterinary Medicine \\ Federal University of Agriculture, Abeokuta \\ ${ }^{2}$ Department of Veterinary Parasitology and Entomology, Faculty of Veterinary Medicine \\ University of Ibadan, Ibadan \\ ${ }^{3}$ Department of Veterinary Medicine, College of Veterinary Medicine \\ Federal University of Agriculture, Abeokuta \\ Nigeria \\ ${ }^{4}$ Department of Animal Science, Berry College, Mount Berry, GA 30149 \\ USA
}

takeetmi@funaab.edu.ng

\section{ABSTRACT}

Equine theileriosis, an apicomplexan debilitating tick-borne parasitic disease of horses has caused considerable havoc to equine production all over the world. There is a dearth of information on the molecular characteristic of the parasites, Theileria equi Laveran, 1901, in Nigeria. Thus, in this study microscopy techniques and PCR were used to detect the T. equi of horses in Ogun, Oyo and Lagos States of Nigeria. We also characterized the partial region of $18 \mathrm{~S}$ ribosomal RNA gene by sequencing and sequences analysis. One hundred and two horses consisting of Argentine 34 (33.3\%), Sudanese $21(20.6 \%)$ and local breeds $47(46.1 \%)$ including 2 females and 100 males were randomly sampled from the
Polo Clubs in Ibadan, Lagos and from privately owned horse stables in Abeokuta. Blood samples were collected from the jugular vein, thin smears were prepared and stained with a field stain. The DNA was extracted from the blood and a partial region of the $18 \mathrm{~S}$ ribosomal RNA gene was amplified. The amplified products were sequenced unidirectionally and subjected to phylogenetic analysis with those sequences obtained from the GenBank. Of the 102 horses tested, 12 (11.7\%) were positive for T. equi by microscopy which included 9 (19.1\%) local breeds, 2 (5.8\%) Argentine breed and 1 (4.8\%) Sudanese breed. In contrast, $7(6.8 \%)$ were positive by the PCR method; out of which $5(\mathbf{1 0 . 6} \%)$ of these samples were from the local breed of horses while the remaining $2(5.8 \%)$ were from the Argentine breed. The Packed 
Cell Volume (PCV) of the infected and non-infected horses did not show any significant $(\mathrm{P}<0.05)$ difference. The sequences lengths obtained were $311 \mathrm{bp}$ and they had 97.43-98.07\% homologies with available sequences in the GenBank. The phylogenetic analysis of the sequences suggested that the strain of T. equi detected in the study area formed a new genotype different from the established genotypes around the world. In conclusion, the prevalence of $T$. equi was very low in the study area and one strain of the parasite may be in circulation among the studied horses.

Key words: equine theileriosis; horse; Nigeria; polymerase chain reaction; Theileria equi

\section{INTRODUCTION}

Equine theileriosis is an apicomplexan debilitating protozoan parasitic disease of horses, mules, donkeys and zebras. It is caused by a tick-borne intra-cellular protozoan parasite Theileria equi Laveran 1901, (formerly Babesia equi) $[18,22]$. The parasite is transmitted horizontally by ticks of the genera Rhipicephalus, Dermacentor, and Hyalomma, [25]. Theileria equi in their mammalian host exhibits a biphasic life cycle which involves an intra-leucocytic developmental phase that is followed by an intra-erythrocytic stage [20,24]. During the later phase, the disease is characterized by: fever, anaemia, icterus, hepatomegaly, splenomegaly, intravascular haemolysis, petechial haemorrhages of the mucous surfaces, haemoglobinaemia, and haemoglobinuria $[5,18]$.

Equine theileriosis has a cosmopolitan distribution, being endemic in most tropical and subtropical areas of the world, as well as in some temperate climatic zones. Once a horse is infected, it becomes a carrier and thus serves as a potential reservoir for the dissemination of the parasite $[6,31]$ to susceptible animals. The diagnosis of equine theileriosis can be made from a combination of clinical signs, examination of stained blood in a susceptible animal [16], PCR, [19, 31] and serological techniques $[1,8$, 31]. While the clinical signs of equine piroplasmosis due to T. equi and Babesia caballi are not distinguishable, microscopy has been reported to fail in detecting T. equi in low parasitaemic horses. These, as well its microscopical techniques failure to differentiate artefacts from the small sized
T. equi in blood smears makes microscopy not suitable for adequate diagnosis of equine theileriosis. On the other hand, serological methods are generally known not to be able to differentiate between active and previous infections and thus may lead to a false positive diagnosis [12].

Several studies have alluded to the superiority and sensitivity of molecular techniques in the detection and characterization of $T$. equi in the family equidae $[4,9,15,17,21$, $28,29,30$ ]. In a recent report, $\mathrm{W}$ a $\mathrm{n} g$ et al. [30] have been able to establish the existent five genotypes (A, B, C, D, E) of T. equi around the world but no T. equi sequences from Nigeria were included in the analysis.

Equine piroplasmosis due to B. caballi and T. equi has been detected and reported in Nigeria using microscopic $[7,13,26]$ and serological [8] methods but no research effort has been made for the detection and characterization of the species and genotype of T. equi in Nigeria using a molecular approach.

This study was conducted to assess the prevalence and molecular characteristic of T. equi in naturally infected horses in Nigeria by analysis of partial sequence of $18 \mathrm{~S}$ ribosomal RNA gene (18S rRNA).

\section{MATERIALS AND METHODS}

\section{Study area}

The study was carried out in the South West zone of Nigeria which included Abeokuta, Ibadan and Ikeja of Ogun, Oyo and Lagos States, respectively (Fig. 1). Ogun State borders Lagos State to the south and Oyo State to the north. The vegetation pattern of Oyo state is that of rain forest in the south and guinea savannah in the north, Ogun Sate is a swampy rain forest and derived forest vegetation while that of Lagos is mainly a mangrove swamp forest. The average rainfall in the three States are $1468.2 \mathrm{~mm}, 1470.0 \mathrm{~mm}$ and $1631.8 \mathrm{~mm}$ for Ogun, Oyo and Lagos States, respectively, with average temperatures of $35.5^{\circ} \mathrm{C}, 31.5^{\circ} \mathrm{C}$ and $30.7^{\circ} \mathrm{C}$, respectively [3].

\section{Samples}

One hundred and two horses were randomly selected from two polo clubs, one each from Ibadan and Lagos, and from privately owned horse stables from Ogun State. The breed, sex and the age of the horses were recorded. Blood samples were collected from the jugular vein of each ani- 


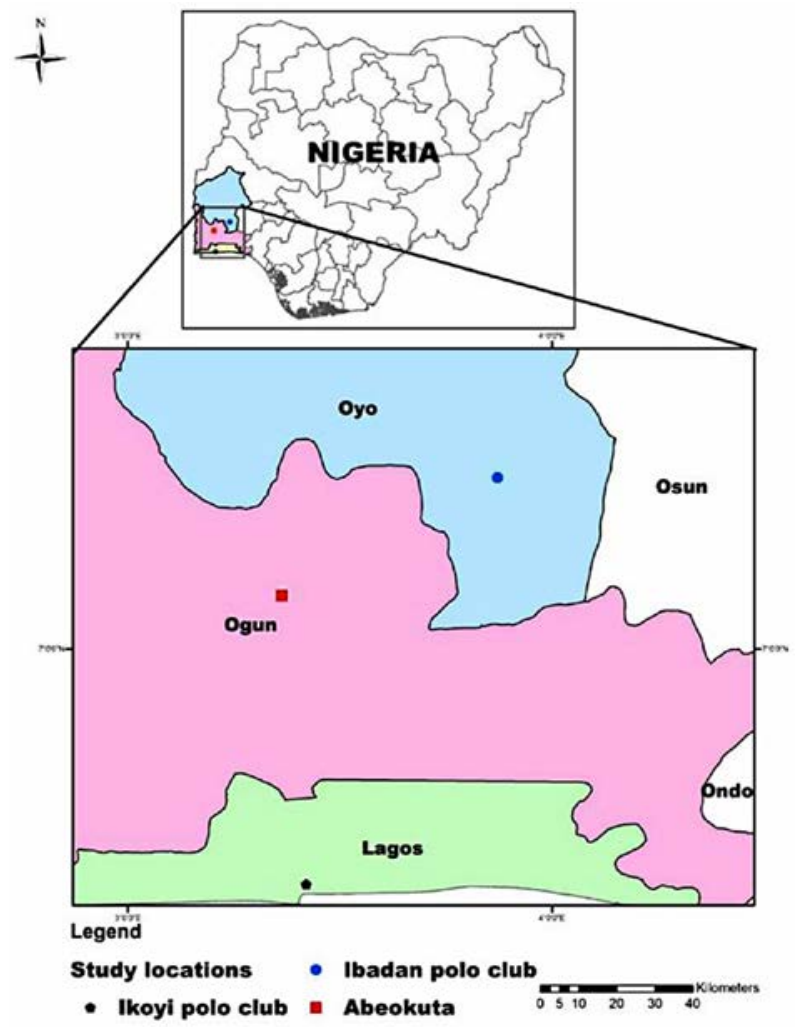

Fig. 1. Map of Nigeria showing the states where samples were collected from horses

mal into vials containing EDTA as the anticoagulant. The blood was stored and transported in an ice pack to the Veterinary Parasitology Laboratory, Federal University of Agriculture, Abeokuta for analysis. The aliquots of the blood samples meant for PCR were store in $-20^{\circ} \mathrm{C}$ freezers until their use for DNA extraction.

\section{Haematology and Theileria equi detection by microscopy}

The packed cell volume (PCV) of each blood sample was determined by the haematocrit centrifugation techniques. The buffy coat from each capillary tube was expressed on to a clean slide, covered with a slip and checked for heamoflagellate with the $\mathrm{x} 40$ objective lens. A thin blood smear was made, air dried and fixed with methanol after which the slides were reverse stained with Field stains A and B. The stained slides were examined under the x100 objective with oil immersion with the light microscope (Olympus, USA). Demonstrations of pyriform or round shape piroplasm in the red blood cells were taken to be positive for Theileria species in the blood samples collected.

\section{DNA extraction}

The DNA was extracted from each blood sample using the "Macherey-Nagel's DNA blood kit" (Macherey-Nagel, Germany). The extraction was done as described by the manufacturer as follows: Blood samples were removed from the freezer and allowed to thaw at room temperature. Thereafter, $200 \mu \mathrm{l}$ of blood and $25 \mu \mathrm{l}$ of proteinase $\mathrm{K}$ were pipetted into $1.5 \mathrm{ml}$ microcentrifuge tubes, after which $200 \mu$ of genomic lysis buffer (Buffer B3) was added to the samples and vortexed vigorously for 10 seconds. The mixtures were incubated at $70{ }^{\circ} \mathrm{C}$ for $10 \mathrm{~min}$, after which $210 \mu \mathrm{l}$ of ethanol was added to each sample and were all vortexed again. For each mixture, one NucleoSpin ${ }^{\circledR}$ Blood Column was taken and placed in a collection tube and the samples were loaded and centrifuged for 1 minute at $11,000 \times \mathrm{g}$, after which the collection tube with flowthrough were discarded. The NucleoSpin ${ }^{\circledast}$ Blood Column was placed into a new collection tube $(2 \mathrm{ml})$ and $500 \mu \mathrm{l}$ binding buffer (Buffer BW) was added and centrifuged for $1 \mathrm{~min}$ at $11,000 \times \mathrm{g}$. Again the flow through was discarded and the collection tube reused. The NucleoSpin ${ }^{\circledR}$ Blood Column was placed back into the collection tube and centrifuged for $1 \mathrm{~min}$ at $11,000 \times \mathrm{g}$ to remove residual ethanol. After the removal of the residual ethanol, the NucleoSpin ${ }^{\circ}$ Blood Column was placed in a $1.5 \mathrm{ml}$ microcentrifuge tube and $100 \mu$ preheated elution buffer (Buffer BE) was dispensed directly onto the silica membrane and incubated at room temperature for $1 \mathrm{~min}$, after which it was centrifuged for $1 \mathrm{~min}$ at $11,000 \times \mathrm{g}$. The eluted DNA concentration was measured using a nanodrop US spec (USA) and stored in $-20{ }^{\circ} \mathrm{C}$ freezers until use.

\section{Theileria DNA detection by PCR}

The 18SrRNA gene of Theileria species was targeted for amplification using the primer set designed by $\mathrm{A} 1 \mathrm{~h}$ a s $\mathrm{s}$ a $\mathrm{n}$ et al. [2] and modified by S lo b o d a et al. [23]. The forward primer TBM: CTTCAGCACCTTGAGAGAAATC and the reverse primer for Theileria equi BE R: TGCCTTAAACTTCCTTGCGAT (Bioneer Inc, South Korea) were used to amplify an approximately $360 \mathrm{bp}$ region of the $18 \mathrm{~S}$ rRNA gene of T. equi. The PCR amplification was carried out in a total volume of $25 \mu \mathrm{l}$ containing $12.5 \mu \mathrm{l}$ of $2 \times$ master mix (BioLabs, New England USA), $0.5 \mu \mathrm{l}(10 \mu \mathrm{M})$ each of the reverse and forward primers, $9 \mu$ nuclease free water and $2 \mu \mathrm{l}$ of the DNA samples. The amplification was carried out using MJ Mini 48-Well Personal Thermo Cycler 
(Bio-Rad Inc., USA) with the following program: an initial denaturation at $94^{\circ} \mathrm{C}$ for $5 \mathrm{~min}, 35$ cycles of denaturation, annealing and extension at $94^{\circ} \mathrm{C}, 58.5^{\circ} \mathrm{C}$ and $72{ }^{\circ} \mathrm{C}$ for $30 \mathrm{~s}, 60 \mathrm{~s}$, and $45 \mathrm{~s}$, respectively, and the final extension at $72{ }^{\circ} \mathrm{C}$ for $10 \mathrm{~min}$. The DNA extracted from the blood of horse that tested positive for T. equi by microscopy and nuclease free water were used as the positive and negative controls in all the reactions, respectively.

\section{Gel electrophoresis, sequencing and sequence analysis}

The PCR products were resolved in $1 \%$ ethidium bromide stained agarose dissolved in Tris-acetate-EDTA (TAE) buffer for $60 \mathrm{~min}$ at 90 volts and documented under an ultraviolet transilluminator to determine the positivity of the samples. The PCR products that showed the expected band sizes for T. equi were unidirectionally sequenced using the reverse primer in Cornell University core laboratory facility, Ithaca, New York. The sequences obtained were manually cleaned, aligned using ClustalW in the software of BioEdit Sequence Alignment Editor and the phylogenetic tree constructed using Neighbour Joining algorithm in MEGA 5.0 software. The obtained sequences reported in this study were deposited and available in the NCBI data base under the accession numbers MN785125-MN785128.

\section{Statistical Analysis}

Data obtained for haematology were presented as means \pm standard deviations. The differences in mean PCV values were compared using the student T-test in SPSS version 19.

\section{RESULTS}

\section{Animals sampled and microscopy}

One hundred and two horses consisting of Argentine (34), Sudanese (21) and local (47) breeds were sampled from the polo clubs in Ibadan and Lagos, and from privately owned horse stables in Abeokuta. The privately owned horses were ceremonial and dressed horses; 100 (98.04 \%) and $2(1.96 \%)$ were male and female, respectively. The Theileria spp. were detected in thin smears of $12(11.76 \%)$ of the horses which include 9 (19.1\%) local breeds, 2 (5.8\%) Argentine breed and 1 (4.8\%) Sudanese breed. In contrast, 7 (6.8 \%) were positive by PCR, out of which 5 (10.6\%) of these samples were from the local breed of horses, while the remaining 2 (5.8\%) were from the Argentine breed. The horses from Abeokuta had higher incidences and all of the positive samples were from the male horses.

\section{Determination of PCV}

The PCV of the horses ranged from $29.6 \%$ to $45.1 \%$. The Argentine had an average PCV of $32.7 \pm 0.6179 \%$, Sudan had $31.1 \pm 0.2526 \%$ and Nigerian local breed had $30.7 \pm 0.1035 \%$. The infected and non-infected horses were not significantly different $(\mathrm{P}>0.05)$ in their PCV values. In general, the mean PCV values of those horses that tested positive and negative for T. equi by microscopy were $35.08 \%$ and $32.97 \%$, respectively and those detected molecularly were $32.86 \%$ and $30.08 \%$, respectively. These values were not significantly different between those infected and non-infected by T. equi.

\section{Molecular detection and sequence analysis}

The PCR products from 7 (6.9\%) horses (Table 1$)$ revealed a band size of about $360 \mathrm{bp}$ which was the expected band size for T. equi and no sample was positive for the

Table 1. Prevalence of Theileria equi in naturally infected horses from three western states in Nigeria detected by the polymerase chain reaction

\begin{tabular}{lccccccc}
\hline & \multicolumn{2}{c}{ Argentine Horses (\%) } & \multicolumn{2}{c}{ Local Horses (\%) } & \multicolumn{2}{c}{ Sudanese Horses (\%) } & Total \\
\cline { 2 - 6 } & Infected & Non-infected & Infected & Non-infected & Infected & Non-infected & \\
\hline Abeokuta & $0(0)$ & $3(13.6)$ & $4(18.2)$ & $13(59.1)$ & $0(0)$ & $2(9.1)$ & 22 \\
Ibadan & $1(2.1)$ & $17(36.2)$ & $1(2.1)$ & $17(36.2)$ & $0(0)$ & $11(23.4)$ & 47 \\
Lagos & $1(3.0)$ & $12(36.4)$ & $0(0)$ & $12(36.4)$ & $0(0)$ & $8(24.2)$ & 33 \\
\hline Total & $\mathbf{2 ( 1 . 9 )}$ & $\mathbf{3 2 ( 3 1 . 4 )}$ & $\mathbf{5 ( 4 . 9 )}$ & $\mathbf{4 2 ( 4 1 . 2 )}$ & $\mathbf{0 ( 0 )}$ & $\mathbf{2 1 ( 2 0 . 6 )}$ & $\mathbf{1 0 2}$ \\
\hline
\end{tabular}




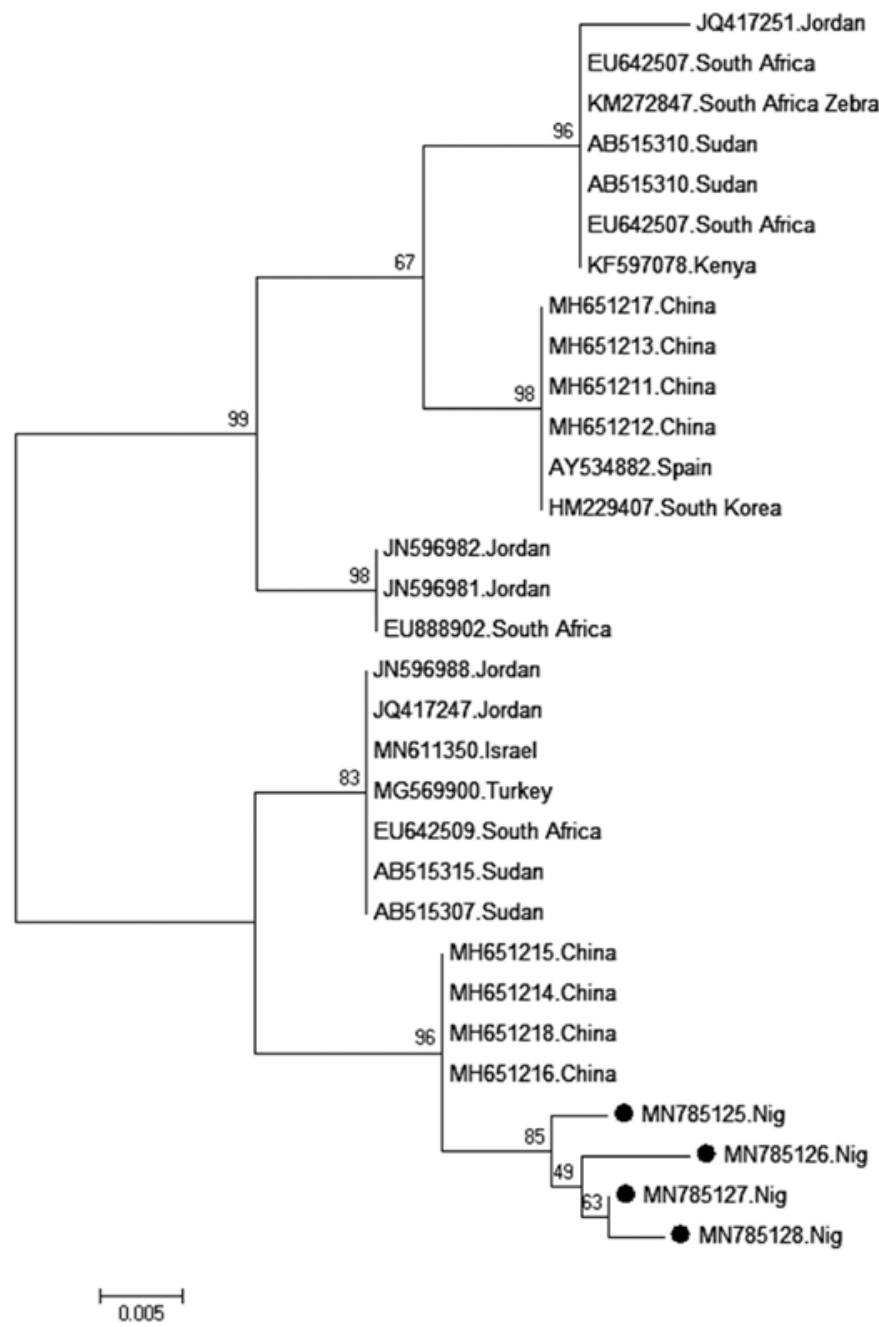

Fig. 2. Phylogenetic analysis of Theileria equi $18 \mathrm{~S}$ rRNA gene partial sequences detected in naturally infected horses from three south western states of Nigeria

The tree was inferred using Neighbour joining algorithms. Numbers above the branches represent bootstrap support from 1000 replications. The sequences from this study are indicated in bold cycle and others from the GenBank database are shown with Accession No., and country of their geographical origin

DNA of B. caballi. The sequences obtained were subjected to a BLAST search in the GenBank and the four sequences had $97.43-98.07 \%$ similarity with those available from the 18S rRNA gene sequences in the GenBank (MN611348 and MG052915). Also, pair wise comparison of the sequences from this study revealed a similarity of 99.03-99.35\%. The aligned sequences were less polymorphic except at point 13 where sample 3 and 37 had alteration of $A \rightarrow G$ and $A \rightarrow C$, respectively. The tree inferred by the Neighbour Joining algorithm in the phylogenetic analysis of $18 \mathrm{~S}$ rRNA gene partial sequences placed the sequences of T. equi from this study in a single or monophylectic clade that was completely separated from other sequences around the world, but situated closer to some of the sequences of T. equi detected from the Gansu Province in China. Also, to mention that some sequences of Africa origin (Kenya, Sudan, South Africa) are distantly separated from the autochthonous sequences (Fig. 2).

\section{DISCUSSION}

Equine theileriosis, a debilitating parasitic disease of horses has been studied extensively using microscopical and serological techniques in Nigeria [8, 13, 14, 27]. Whereas, no study yet assessed the prevalence of equine 
theileriosis in the south western part of Nigeria, none has used molecular methods for the detection and genetic characterization of T. equi in Nigeria. This study therefore, detected by microscopy the T. equi of horses in Ogun, Oyo and Lagos States of Nigeria and characterized the partial region of $18 \mathrm{~S}$ rRNA gene sequences by sequences analysis. In our study, we confirmed an $11.7 \%$ prevalence of equine theileriosis in the investigated horse population. Our finding was within the range of prevalences that were variously reported in Northern Nigeria [13,27] but much lower than $77 \%$ and $57 \%$ prevalences reported by $\mathrm{M} \mathrm{sheli}$ a et al. [13] and E m e m u et al. [8], respectively using serological techniques in Nigeria. The higher prevalences by serology may be due to lingering antibodies produced against invading pathogens that had been cleared from the circulation. In contrast, the molecular techniques from this study revealed a prevalence of 7 (6.9\%) that was lower than the value detected by microscopy. The region of the gene targeted for the detection of this parasite has been adjudged to be a very sensitive region for the detection of T. equi [10, $11,23]$, and as such would be expected to be more sensitive than the microscopy method. Hence, the PCR prevalence result that was lower than that of microscopy may only suggest that those positive samples by microscopy that became negative by PCR were other species of piroplasm in the horse population sampled other than the T. equi and B. caballi screened in this study. Therefore, future screening for piroplasm of horses should be widened to check for other species. The detection of more Theileria in horses from Abeokuta may suggest that horses from polo clubs get more attention than those from privately owned horses in term of regular cleaning, ectoparasites control and grooming by the animal handlers.

The infected horses were slightly anaemic and this observation was in line with our previous report of slightly anaemic horses presented to the Veterinary Teaching Hospital in the study area in Nigeria by $\mathrm{T}$ a ke e $\mathrm{t}$ et al. [26] and that of $\mathrm{Z} \mathrm{ob}$ a et al. [32] in Sardinia, Italy. The obtained partial sequences of T. equi 18S rRNA gene formed a monophyletic clade that is well separated from other clades on the phylogenetic tree and as such may suggest that only one strain of the parasite was present among the horse population in the study area. Also, the analysis of autochthonous sequences with those analysed by $\mathrm{W}$ a $\mathrm{ng}$ et al. [30] suggested that the genotype formed by the sequences from this study may be different from the established genotypes around the world [30] and as such assigned genotype F (Fig. 2). This suggestion was strongly supported by the inferred phylogenetic tree that exhibit clustering together by those sequences from this study. Although the number of samples collected in this study may not be robust enough to conclude that only one strain is available in Nigeria, there may be a need to increase the sample population in order to be able to draw an inference with a larger scale.

\section{CONCLUSIONS}

In conclusion, this study was the first report of the molecular detection of T. equi in Nigeria. The prevalence of T. equi was low in the study area and the assessment of the $18 \mathrm{~S}$ rRNA gene sequences suggested that only one strain of T. equi was in circulation among the horse population studied.

\section{ACKNOWLEDGEMENTS}

The authors wish to thank Mr. Olugbogi E. I. for his technical support in the Veterinary Parasitology laboratory. We also wish to thank the Director of Veterinary Teaching Hospital, College of Veterinary Medicine, FUNAAB, Dr. Sonibare, A. O. for linking us with the various polo clubs and private horse owners during the collection of the blood samples.

\section{REFERENCES}

1. Abedi, V., Razmi, G., Seifi, H., Naghibi, A., 2014: Molecular and serological detection of Theileria equi and Babesia caballi infection in horses and ixodid ticks in Iran. Ticks and TickBorne Dis., 5, 239-244. DOI: 10.1016/j.ttbdis.2013.11.008.

2. Alhassan, A., Wilawan, P., Okamura, M., Hirata, H., Battsetseg, B., Fujisaki, K., et al., 2005: Development of a single-round and multiplex PCR method for the simultaneous detection of Babesia caballi and Babesia equi in horse blood. Vet. Parasitol., 129, 43-49. DOI: 10.1016/j.vetpar. 2004.12.018.

3. Aribisala, J. O., Ogundipe, O. M., Akinkurolere, O. O., 2016: The study of climate change. Br. J. Appl. Sci. Technol., $13,6,1-7$.

4. Braga, M., Costa, F. N., Gomes, D. R. M., Xavier, D. R., 
Andre, M. R., Goncalves, L. R., et al., 2017: Genetic diversity of piroplasmids species in equids from island of Sao Luis, northeastern Brazil. Rev. Bras. Parasitol. Vet., 26, 331-339. DOI: 10.1590/S1984-29612017046.

5. Brooks, L., Cordes, T. D., Stiller, D., 1996: Piroplasmosis of horses. What is known concerning transmission and disease risk. J. Equine Vet. Sci., 16, 184-188. DOI: 10.1016/S07370806(96)80110-9.

6. Bruning, A., 1996: Equine piroplasmosis. An update on diagnosis, treatment and prevention. Br. Vet. J., 152, 139-151. DOI: 10.1016/S0007-1935(96)80070-4.

7. Ememu, M. U., Onyegbola, O., Egwuogu, F. C., Nlebedum, C. U., Ogbu, C. C., 2018: Babesia caballi infection in a 6-month old colt. Sokoto Journal of Veterinary Sciences, 16, 1, 102-106. DOI: 10.4314/sokjvs.v16i1.15.

8. Ememu, M. U., Tekdek, L. B., Ayo, J. O., 2019: Serological investigation of the Theileria equi and Babesia caballi infections in horses in Porthacourt Polo Club, Nigeria. Nigeria Journal of Parasitology, 40, 2, 291-295. DOI: 10.4314/njpar.v40i2.28.

9. Hall, C. M., Busch, J. D., Scoles, G. A., Palma-Cagle, K. A., Ueti, M. W., Kappmeyer, L. S., Wagner, D. M., 2013: Genetic characterization of Theileria equi infecting horses in North America: evidence for a limited source of U.S. introductions. Parasit. Vectors, 6, 35. DOI: 10.1186/1756-3305-6-35.

10. Kizilarslan, F., Yildirim, A., Duzlu, O., Inci, A., Onder, Z., Ciloglu, A., 2015: Molecular detection of Theileria equi and Babesia caballi in horses (Equusferus caballus) in Turkey. J. Equine Vet. Sci., 35, 10, 810-835. DOI: 10.1016/j.jevs.2015. 08.002 .

11. Leal, D. C., Madruga, C. R., Matos, P. F., Souza, B. M. P. S., Franke, C. R., 2011: Evaluation of PCR and multiplex PCR in relation to nested PCR for diagnosing Theileria equi. Pesq. Vet. Bras., 31, 7, 575-578. DOI: 10.1590/S0100736X2011000700005.

12. Malekifard, F., Tavassoli, M., Yakhchali, M., Darvishzadeh, R., 2014: Detection of Theileria equi and Babesia caballi using microscopic and molecular methods in horses in suburb of Urmia, Iran. Vet. Res. Forum, 5, 2, 129-133.

13. Mshelia, W. P., Sambo, K. W., Adamu, S., Edeh, E. R., Onoja, I. I., 2016: Persistence of equine piroplasmosis in horses in Nigeria. J. Equine Vet. Sci., 39, 2016, S98-S107.

14. Ola-Fadunsin, S. D., Karaye, P. G., Dogo, G. A., 2018: Haemoparasite fauna of domestic animals in Plateau State, North Central Nigeria. Bayero Journal of Pure and Applied Sciences, 11, 2, 156-161. DOI: 10.4314/bajopas.v11i2.19.

15. Peckle, M., Pires, M. S., Silva, C. B. D., Costa, R. L. D., Vi- tari, G. L. V., Senra, M. V. X., et al., 2018: Molecular characterization of Theileria equi in horses from the state of Rio de Janeiro, Brazil. Ticks and Tick-Borne Dis., 9, 349-353. DOI: 10.1016/j.ttbdis.2017.11.011.

16. Phipps, L. P., 1996: Equine piroplasmosis. Equine Vet. Educ., $8,33-36$.

17. Qablan, M. A., Obornik, M., Petrzelkova, K. J., Sloboda, M., Shudiefat, M. F., Horin, P., et al., 2013: Infections by Babesia caballi and Theileria equi in Jordanian equids: epidemiology and genetic diversity. Parasitology, 140, 1096-1103. DOI: $10.1017 / \mathrm{s} 0031182013000486$.

18. Radostitis, O. M., Gay, C. C., Blood, D. C., Hinchiff, K. W., (Eds.), 2000: Veterinary Medicine. A Textbook of the Disease of Cattle, Sheep, Goats and Horses. 9th edn., W. B. Saunders Co. London, New York, Philadelphia, 1261-1265.

19. Rampersad, J., Cesar, E., Campbell, M. D., Samlal, M., Ammons, D., 2003: A field evaluation of PCR for the routine detection of Babesia equi in horses. Vet. Parasitol., 114, 81-87. DOI: 10.1016/so304-4017(03)00129-8.

20. Ramsay, J. D., Ueti, M. W., Johnson, W. C., Scoles, G. A., Knowles, M. D. P., 2013: Lymphocytes and macrophages are infected by Theileria equi, but T cells and B cells are not required to establish infection in vivo. PLOS ONE, 8, 10, e76996. DOI: 10.1371/journal.pone.0076996.

21. Seo, M. G., Yun, S. H., Choi, S. K., Cho, G. J., Park, Y. S., Cho, K. H., et al., 2013: Molecular and phylogenetic analysis of equine piroplasms in the Republic of Korea. Res. Vet. Sci., 94, 579-583. DOI: 10.1016/j.rvsc.2013.01.014.

22. Singla, L. D., Sumbria, D., 2019: Cutting edge meticulous appraisal of equine piroplasmosis in India and in the rest of the globe. Indian J. Vet. Med., 39, 01, 1-10.

23. Sloboda, M., Jirku, M., Lukešova, D., Qablan, Q., Batsukh, Z., Fiala, I., et al., 2011: A survey for piroplasmids in horses and Bactrian camels in North-Eastern Mongolia. Vet. Parasitol., 179, 2011, 246-249. DOI: 10.1016/j.vetpar.2011.01.064.

24. Sumbria, D., Moudgil, A. D., Singla, L. D., 2014: Equine piroplasmosis: Current status. Veterinaria, 2, 1, 9-14.

25. Sumbria, D., Singla, L. D., Sharma, A., Bal, M. S., 2018: Detection of Theileria equi infection of Ixodid ticks in equines using nested polymerase chain reaction from Punjab province. India J. Anim. Sci., 88, 10, 1127-1132.

26. Takeet, M. I., Adeleye, A. I., Adebayo, O. O., Akande, F. A., 2009: Haematology and serum biochemical alterations in stress induced equine theileriosis. A case report. Sci. World J., $4,2,19-21$.

27. Turaki, U. A., Kumsha, H. A., Biu, A. A., Bokko, P. B., 2014: 
Prevalence of piroplasmosis amongst local horses in Northeastern Nigeria. J. Agric. Vet. Sci., 7, 4-7. DOI: 10.9790/2380071240407.

28. Veronesi, F., Morganti, G., Ravagnan, S., Laus, F., Spaterna, A., Diaferia, M., et al., 2014: Molecular and serological detection of tick-borne pathogens in donkeys (Equus asinus) in Italy. Vet. Microbiol., 173, 348-354. DOI: 10.1016/j.vetmic.2014.08.017.

29. Vieira, M. I. B., Costa, M. M., De Oliveira, M. T., Goncalves, L. R., Andre, M. R., Machado, R. Z., 2018: Serological detection and molecular characterization of piroplasmids in equids in Brazil. Acta Trop., 179, 81-87. DOI: 10.1016/j. actatropica.2017.12.028.

30. Wang J., Liu J., Yang J., Wang X., Li Z., Xu J., et al., 2019:
The first molecular detection and genetic diversity of Babesia caballi and Theileria equi in horses of Gansu province, China. Ticks and Tick-Borne Dis., 10, 528-532. DOI: 10.1016/j.ttbdis.2019.01.003.

31. Ybañez, A. P., Ybañez, R. H. D., Talle, M. G., Arreglo, R M. T., Geens, M. J. C., Villas, J. G. I., et al., 2018: Serological and molecular detection of Theileria equi and Babesia caballi in Philippine horses. Ticks and Tick-Borne Dis., 9, 1125-1128. DOI:10.1186/s13071-016-1539-9.

32. Zoba, R., Ardu, M., Niccolini, S., Chessa, B., Monna, L., Cocco, R., et al., 2008: Clinical and laboratory findings in equine piroplasmosis. J. Equine Vet. Sci., 2, 5, 301-308. DOI: 10.1016/j.jevs.2008.03.005.

Received July 6, 2020

Accepted September 10, 2020 